\section{AZ ESETTANULMÁNY-MÓDSZER ALKALMAZÁSA A BIZTOSÍTÁ- SI SZEKTOR ISMERTSÉGÉNEK NÖVELÉSE ÉRDEKÉBEN}

\section{Ábrahám Zsolt (a Case Solvers alapitója)}

\section{ÖSSZEFOGLALÓ}

A tanulmányban bemutatott kutatás a biztosítási szektor ismertségét vizsgálta üzleti egyetemista diákok körében. A tanulmány célja kettős: egyrészt egy fókuszcsoportos kutatáson keresztül bemutatja, hogy mennyire ismerik a hazai egyetemisták a biztositási szektort, másrészt a 2017 novemberében megrendezett „Biztosítsd Be Magad” esettanulmány-versenyen keresztül megvizsgálja, hogy miként alkalmazható a módszer az iparág ismertségének növelésére az Y generáció körében. A fókuszcsoportos kutatás alapján megállapítható, hogy az egyetemista hallgatók nem ismerik a biztosítási szektor működését, termékeit, szereplöit, illetve a szektor szereplöi által nyújtott karrierpályákat. A versenyre leadott megoldások értékelése alapján kimondható, hogy az esettanulmány-módszer, illetve az esettanulmány-verseny mint formátum alkalmas arra, hogy a szektorral kapcsolatos alapvető szakmai ismereteket adjon át.

\section{SUMMARY}

This paper is based on a research which focused on the awareness of university students in Hungary concerning the insurance industry. The study has multiple objectives: (1) it investigates the awareness of university students through a focus group research, (2) and it applies the case study of a case competition (Biztosítsd Be Magad) to illustrate how the case method is an effective tool to increase awareness and educate Gen-Y students about the insurance sector. As a conclusion of the focus group this paper concludes that university students have no extensive knowledge about the sector, they are lacking basic information about the operation, products, players and the regular career paths of this industry. Based on the analysis of the team solutions delivered by the case competition participants it is argued that the method and the case competition format is capable to educate university students and equip them with new type of knowledge about a specific industry.

Kulcsszavak: Y generáció, esettanulmány-módszer, esettanulmány-verseny, biztosítási szektor, ismertség

Keywords: Generation Y, case method, case competition, insurance sector, awareness

\section{JEL: G22, C83}

DOI: $10.18530 / \mathrm{BK} .2018 .3 .76$

http://dx.doi.org/1018530/BK.2017.3.76

\section{BEVEZETÉS}

Gyakori közhely, hogy a mai fiatalok már nem olyanok, mint az idősebb generáció tagjai. Máshogy látják a világot, nem az érdekli őket, mint minket vagy mint a szüleinket. A probléma nem új, mindig is létezett és létezni is fog. Ahogy a világ változik, a technológia fejlődése hatással van mindennapi életünkre, és ez a hatás minden egyes nemzedék esetében eltérő. Más környezetbe születtünk, más hatások érnek minket, eltérő élethelyzetek, motivációk alakulnak ki. Egyénként és vállalatvezetőként fontos, hogy ezeket a helyzeteket felismerjük, és a változások élére álljunk.

Jelen tanulmány a biztosítási szektor és az Y generáció kapcsolatát vizsgálja az esettanulmány-módszeren keresztül. Arra a kérdésre keresi a választ, hogy mennyire ismert a biztositási szektor az Y generáció körében, illetve az ismertséget hogyan lehet javitani a szektor esetében az esetversenyeken keresztül. A tanulmányban bemutatott kutatás a MABISZ Y generáció munkacsoportjának készült 2017-ben márciusában a Case Solvers ${ }^{1}$ közreműködésével.

A kutatás módszertana két pilléren nyugszik. Egy fókuszcsoportos kutatás arra kereste a választ, hogy az egyetemisták mennyire ismerik a biztosítási szektort, annak termékeit, és mennyire tekintenek a biztosítókra potenciális munkaadókként. A módszertan második lábát a 2017 szeptembere és novembere között megszervezésre került „Biztosíts Be Magad” esettanulmány-verseny jelenti, melynek legfőb célkitűzése az Y generáció iparági edukációja, valamint az iparág ismertségének javítása volt. Az itt szerzett tapasztalatokat mutatom be.

A tanulmány első fejezeteiben az Y generáció és a biztosítók kapcsolatát, valamint az esettanulmány-módszert mutatom be, majd részleteiben ismertetem a kutatás módszertanát és a „Biztosítsd Be Magad” esettanulmány-verseny koncepcióját. Az utolsó fejezet a fókuszcsoportos kutatást taglalja, az esetverseny tapasztalatait és az azokhoz kapcsolódó következtetéseket fejti ki.

\section{AZ Y GENERÁCIÓ ÉS A BIZTOSÍTÓK}

Ahhoz, hogy a biztosítási szektor és az Y generáció kapcsolatát vizsgáljuk, fontos, hogy definiáljuk, mit is tekintünk generációnak. McCrindle és Wolfinger (2014) szerint a generációkat egy sajátos időszak határozza meg. Egy generációra tekinthetünk úgy, mint olyan személyek csoportjaira, akik azonos történelmi időn és téren osztoznak, és mindez egy kollektív személyiséget biztosít a csoport tagjai számára.

Az elmúlt évszázad társadalmi, gazdasági és technológiai fejlődése jelentős hatással volt (és van) az egyes generációk életére. A tanulmány a generációk csoportosítása során a szociológiában általánosan elfogadott kategóriákra épül. Eszerint megkülönböztethetünk veteránokat, baby boomereket, valamint X, Y és Z generációt. Az egyes generációk jellemzőit az 1. táblázat mutatja be. 


\section{1. táblázat: A generációk bemutatása}

Generáció Születési év Jellemzök

\begin{tabular}{|c|c|c|}
\hline Veterán & $1925-1945$ & $\begin{array}{l}\text { A II. világháború és a következtében fellépő gazdasági világválság } \\
\text { jelentősen befolyásolta az életüket. Időskorukban találkoztak először } \\
\text { az internettel és az informatikai eszközökkel. Számukra a számítógép } \\
\text { használata kihívást jelent, nehezen tudnak megbirkózni a digitális } \\
\text { társadalom kihívásaival. } \\
\text { A munkával kapcsolatos általános hozzálllásuk: szabályokhoz való } \\
\text { ragaszkodás, konformitás, áldozathozatal, lojalitás. }\end{array}$ \\
\hline Babyboom & $1946-1964$ & $\begin{array}{l}\text { A generáció tagjai megtapasztalták a háborúk és polgárjogi mozgal- } \\
\text { mak előnyeit és hátrányait. Nagy hatással volt a generációra a szexuális } \\
\text { forradalom, valamint a hidegháború tapasztalata. A digitális technoló- } \\
\text { giával és az internettel életük derekán találkoztak. A munkavégzésük- } \\
\text { be csak hellyel-közzel épült be a számítógép-használat. } \\
\text { A munkával kapcsolatos általános hozzállásuk: egyenlőség, opti- } \\
\text { mizmus, lojalitás, csapatszellem. }\end{array}$ \\
\hline X generáció & $1965-1979$ & $\begin{array}{l}\text { A generáció tagjait gyakran digitális bevándorlónak is hívják, mivel } \\
\text { ök azok, akik ifúkorukban találkoztak először a számítógéppel és in- } \\
\text { ternettel, és széles körben használják azt. A generáció tagjaira hatással } \\
\text { volt a nők munkába állása, gyakran tapasztaltak meg olyan családot, } \\
\text { ahol a gyermekeknek magukról kellett gondoskodniuk. Szélsőségesen } \\
\text { élték meg a rendszerváltást, melynek vesztesei vagy éppen nyertesei } \\
\text { voltak. A munkával kapcsolatos általános hozzáálásuk: technológiaörült, } \\
\text { független, magas munkaelvárások. }\end{array}$ \\
\hline Y generáció & $1980-1995$ & $\begin{array}{l}\text { Egy rendkívül gyors technológiai fejlődés időszakában nőttek fel, } \\
\text { ami jelentős hatással volt a globalizációra. A generáció tagjai számára } \\
\text { szimbolikus esemény a rendszerváltás és a Disney-mesék megszakítása } \\
\text { Antall József halála miatt. Magabiztosan kezelik a technológiai eszkö- } \\
\text { zöket, és szabadidejük nagy részét az interneten töltik. Az Y generáció } \\
\text { tagjai már jelen vannak a munkaerőpiacon. } \\
\text { A munkával kapcsolatos általános hozzáállásuk: magabiztosság, } \\
\text { asszertivitás, versenyszellem, azonnal akarás és praktikusság. }\end{array}$ \\
\hline
\end{tabular}

\begin{tabular}{l|l} 
Z generáció & $1996-\quad \begin{array}{l}\text { A nemzedék tagjai sosem éltek olyan társadalomban, ahol ne létezett } \\
\text { volna internet. Ebböl fakadóan idejük és szociális életük jelentős részét } \\
\text { töltik online. A generáció tagjai napjainkban jelennek meg a munka- } \\
\text { eröpiacon. }\end{array}$
\end{tabular}

Forrás: Kulcsár (s.a.), Meretei (2017)

A kutatás tárgyát az Y generáció tagjai, a jelenlegi egyetemista hallgatók jelentik. Az Y generáció tagjaival kapcsolatban több felületes állítás, sztereotípia is él a köztudatban. Ezek szerint a generáció tagjai felületesek, nem tudnak elmélyülni a munkában, türelmetlenek, nem lojálisak, és a sor még tovább folytatható. Az Y generáció tagjai gyakorlatilag beleszülettek a fogyasztói társadalomba és az arra jellemző folyamatos technológiai innovációkba. Füle (2016) szerint az Y generációnak két sajátossága van, az érzelmi inkontinencia, valamint a „multitasking”, azaz az egyidejűleg több párhuzamos tevékenység végzésére való képesség. A kommunikációs csatornák fejlődésével lehetővé vált az érzések, érzelmek külső környezettel történő azonnali megosztása. Mindez nem segít abban, hogy az egyén belül, saját maga dolgozza fel a saját problémáit, azokra gyakran - például a közösségi médián keresztül - másoktól vár választ. A digitalizációval megnövekedett az egyén körül levő információs zaj, és ezzel párhuzamosan jellemző trend, hogy az Y generáció tagjai párhuzamosan egyre több dolgot csinálnak, és szétszórják a figyelmüket.

Jelen kutatás elsődleges célja az volt, hogy felmérje a biztosítási szektor ismertségét az Y generáció tagjai körében, valamint áttekintse, hogy az iparág ismertsége miként javítható a „Biztosítsd Be Magad” esettanulmány-versenyhez hasonló kezdeményezéseken keresztül.

\section{AZ ESETTANULMÁNY-MÓDSZER}

Az esettanulmány-módszer a Harvard Egyetemen alakult ki, és vált idővel egyre elterjedtebbé a felsőoktatásban. Christopher Langdell 1870-ben lett a Harvard jogi karának dékánja, és első intézkedései közé tartozott, hogy intézményesítette a jogi esettanulmányokon keresztüli oktatást (Weaver, 1991). A módszer az üzleti oktatásba a Harvard Business School 1908-as megalapításával került át. Habár napjainkra az esettanulmány-módszert több tudományterületen is alkalmazzák a jogtól a gazdálkodástudományon át az orvostudományig (Merseth, 1991), jelen tanulmány fókuszában az üzleti oktatásban történő alkalmazhatósága áll. Az esettanulmány-módszer tehát egy olyan pedagógiai módszer, mely a példákon - úgynevezett esettanulmányokon - keresztüli oktatást helyezi a középpontba. 


\section{1. Ismeretátadás és kompetenciafejlesztés egyben}

Az esetmódszerrel történő üzleti oktatás középpontjában minden esetben egy rosszul strukturált üzleti probléma áll. A rosszul strukturált probléma jellemzője, hogy túl kevés vagy éppen túl sok információ áll a döntéshozó rendelkezésére, a döntési kritériumok nem jól definiáltak, ebből következően a probléma megoldására sincs egyértelmü kimenet. Az esettanulmány tehát egy valós vagy fiktív üzleti esemény leírása, amely magába foglalja az eseményhez kapcsolódó döntéseket, kihívásokat, lehetőségeket, problémákat és attitüdöket, melyekkel egy személy vagy szervezet szembesül (Erskine, Lender, Mauffette-Lender, 1998). Az esettanulmányokra tehát egy esemény, döntési helyzet szimulációjaként is tekinthetünk.

Az esetek a főszereplőik, a fókuszuk és a terjedelmük alapján széles skálán mozoghatnak. Találunk esettanulmányokat kezdő vállalkozásokról, személyes vezetői dilemmákról vagy akár multinacionális vállalatok transzformációiról. Hammond (2002) szerint az esettanulmányok használatának a legfontosabb előnye, hogy a résztvevőket megtanítják a valódi problémák és az azokhoz kapcsolódó kulcskérdések azonosítására. Levin (1995) szerint az esetek oktatási és tanulási céllal kialakított, kontextusba helyezett narratívák, melyek tényszerű és komplex kérdéseket vizsgálnak.

III. 1.1. Ismeretátadás az esetmegoldáson keresztül

Az esettanulmány-alapú oktatás célja, hogy gyakorlati példákon keresztül adjon át ismereteket az egyetemi hallgatóknak. Az esettanulmány-megoldás során a résztvevők 1) probléma-, 2) vállalat-, 3) iparág-, valamint 4) földrajzi piac specifikus ismeretekkel gazdagodhatnak.

1. Problémaspecifikus ismeretek: Minden esettanulmány középpontjában egy rosszul strukturált probléma áll, melynek értelmezéséhez, azonosításához a diákoknak szükségük van problémaspecifikus ismeretekre, melyek kapcsolódhatnak egy-egy funkcionális területhez (pl. pénzügy vagy marketing).

2. Vállalatspecifikus ismeretek: Az esettanulmányok föszereplői vállalati döntéshozók, akiknek döntési helyzetét nagyban befolyásolja a vállalat. Az esettanulmány megoldása során a hallgatók közelebbről megismernek egy-egy vállalatot és annak stratégiáját, termékeit, folyamatait, működését.

3. Iparágspecifikus ismeretek: Minden vállalat egy adott iparágban működik, megvannak a maga beszállítói, fogyasztói és versenytársai, melyektől a feladat megoldása során nem lehet eltekinteni. A diákok feladata tehát a fentieken túl, hogy megismerjék az adott iparágat, annak szereplőit és a szereplőkhöz kapcsolódó dinamikákat.

4. Földrajzi piac specifikus ismeretek: Egy adott földrajzi piachoz kapcsolódó ismeretek (pl. szabályozás, kultúra, demográfia), melyek szükségesek ahhoz, hogy a diákok megértsék a vállalat piacait, valamint megalapozott javaslatot tegyenek egy esetleges új földrajzi piacon történő terjeszkedésre.
Az adott esettanulmány megoldása során a résztvevők információkat gyüjtenek az adott döntési szituációval kapcsolatban. A szükséges információk egy része megtalálható az előre megírt esettanulmányban, illetve az adott szituációtól függően az interneten fellelhető publikus adatokban

\section{1. 2. Kompetenciafejlesztés az esetmegoldáson keresztül}

Boyatzis és társai (2002) az MBA programok képességfejlesztésre gyakorolt hatását vizsgálta. Jerrad (2005) szerint a diákok az esettanulmány-módszeren keresztül tudják fejleszteni a problémamegoldó készségüket, kritikai gondolkodásukat, analitikus készségeiket, valamint együttműködési készségüket. Kreber (2001) szerint az esettanulmány-megoldás folyamata során a diákok a logikus érvelési és intuíciós készségüket használják.

A kutatómunka során nyolc, a problémamegoldó képességek családjába tartozó kompetenciát azonosítottam, melyeket a 2. táblázat foglal össze.

2. táblázat: A problémamegoldó kompetenciák családja

\begin{tabular}{|c|c|}
\hline Problémamegoldó kompetenciák & Kompetencia bemutatása \\
\hline Információk összegyüjtése & $\begin{array}{l}\text { A rendelkezésre álló információk összegyüjtése, új információk } \\
\text { felkutatása, valamint az azokhoz kapcsolódó priorizálás. }\end{array}$ \\
\hline Analitikus képesség & $\begin{array}{l}\text { Jól és rosszul strukturált problémák megfogalmazása és } \\
\text { megoldása. }\end{array}$ \\
\hline Numerikus készség & $\begin{array}{l}\text { A számokkal való bánásmód, különös tekintettel az alapvető } \\
\text { matematikai műveletek magabiztos alkalmazására }\end{array}$ \\
\hline Strukturáló képesség & $\begin{array}{l}\text { Egy-egy probléma elemeire bontása és a kapott elemek rendsze- } \\
\text { rezése. }\end{array}$ \\
\hline Kritikus gondolkodás & $\begin{array}{l}\text { A jól és rosszul strukturált problémák azonosításához és } \\
\text { megoldásához kapcsolódó kritikus szemlélet. }\end{array}$ \\
\hline Szintetizálás & $\begin{array}{l}\text { A részinformációk kombinációjára épülő megoldás } \\
\text { megfogalmazása. }\end{array}$ \\
\hline Döntéshozatal & $\begin{array}{l}\text { Egy problémához kapcsolódó megoldási alternatívák közöttti } \\
\text { választás, adott kritériumok alapján }\end{array}$ \\
\hline Logikus érvelés & $\begin{array}{l}\text { A rendelkezésre álló információk alapján meghozott döntés és a } \\
\text { javaslat mögötti logikus érvelés. }\end{array}$ \\
\hline
\end{tabular}

Forrás: saját koncepció (2018)

Az esettanulmány megoldása során a résztvevők 3-5 fös csapatokban dolgozva információkat gyűjtenek össze, elemeznek, szintetizálnak és strukturálnak. Mindezt időnyomás 
alatt teszik, ami rákényszeríti őket arra, hogy csapatként dolgozva fontosság alapján rendszerezzék a feladatokat, és hatékonyan hozzanak jó döntéseket. A megoldásként elkészített javaslatot egy logikus érvelésbe építik fel, melyet egy szakmai zsűrinek prezentálnak.

\section{2. Játszva tanulás, versenyek és játékos oktatás}

Az esettanulmány-módszer egyik egyedi alkalmazási területe az úgynevezett esettanulmány-verseny. A résztvevők legalább egy rosszul strukturált, komplex üzleti esettanulmányt dolgoznak fel, oldanak meg időnyomás alatt versenyhelyzetben. Az esettanulmány nehézségi fokát általában a rendelkezésre álló idő, valamint az üzleti probléma összetettsége határozza meg. A versenyeken keresztül a résztvevők tesztelik és megmutatják a problémamegoldó képességüket egy szakmai zsűri előtt, amely a verseny végén a hallottak alapján sorrendet állít fel a prezentált megoldások között. A zsűri a versenyszervezők által egy előre meghatározott szempontrendszer alapján kiválasztja a verseny legjobb csapatát.

Az esettanulmány-versenyek a való életben is elterjedt belső és külső tanácsadói projektek laboratóriumi változataiként is felfoghatók. A versenyeknek két föszereplöjük van, a résztvevők, valamint az esettanulmány témáját adó szervezet vagy vállalat (továbbiakban esetszponzor ${ }^{2}$ ). A résztvevők kontrollált körülmények között járnak körbe egy-egy üzleti problémát, melyet aztán strukturált prezentáció formájában adnak elő az adott vállalat vagy szervezet menedzsmentjének.

\section{Az esettanulmány-versenyek a való életben is elterjedt tanácsadói} projektek laboratóriumi változataiként is felfoghatók.

Az esettanulmány-versenyek során a résztvevők csapatban dolgoznak, saját maguk hozzák a belső szabályaikat, megtanulnak együttműködni és feladatot delegálni. A csapatok tagjai előre megtervezik, majd lekövetik az esettanulmány-megoldás folyamatának a főbb lépéseit (Kunselman és Johnson, 2004).

Az esettanulmány-versenyek a felépítésüket tekintve többfélék is lehetnek. A versenyek lehetnek publikusak - azaz bárki jelentkezhet, aki a versenyszabályzatban meghatározott kritériumoknak megfelel - és meghívásosak. Ez utóbbira csak a meghívót kapott szervezetek, intézmények delegálhatnak csapatokat, a versenyszabályzatban leírt feltételek betartása mellett. Az egyenlő feltételek és esélyek biztosítása révén a versenyek egyértelműen definiálják a résztvevők körét. Mindezek alapján vannak alapszakos és mesterszakos hallgatóknak szóló és kevert versenyek.

A formátum alapján megkülönböztethetünk egy és több esettanulmány megoldására épülő versenyt. Az eset(ek) megoldásához rendelkezésre álló idő lehet több mint 24 óra (általában 72 vagy 168 óra), 24 óra, valamint kevesebb mint 24 óra (általában 4, 8 vagy 10 óra).

Maier-Lyte és társai (2010) szerint az esettanulmány-versenyeken való részvétel előnyei négy kategóriába sorolhatók. Egyrészt a résztvevők új, specializált ismeretekkel gazdagodhat- nak, másrészt a kommunikációs és elöadói készségüket fejleszthetik. A harmadik csoportot a csapaton belüli kollaboráció fejlesztése jelenti. A résztvevők megtanulnak csoportosan döntést hozni, hatékonyan feladatot delegálni, valamint időnyomás alatt konstruktívan együtt dolgozni. Végül az esettanulmány-versenyeken keresztül a részt vevő diákok a munkaerőpiacon betöltött pozíciójukat is javíthatják, hiszen egy valós üzleti helyzethez hasonló komplex probléma megoldásán keresztül mutathatják meg rátermettségüket potenciális munkaadóiknak.

A biztosítási szektor ismertségéről szóló kutatás három tényezőt vizsgált: a versenyeken keresztül átadható tárgyi ismereteket, a fejleszthető és mérhető kompetenciákat, valamint a megoldás során a javaslatokban megfogalmazott ötleteket. A 3. táblázat ezeket az előnyöket mutatja be a részt vevő versenyzők és az esetszponzorok szemszögéből

3. táblázat: Az esettanulmány-versenyek előnyei a két föszereplő nézőpontjából

\begin{tabular}{|l|l|l|}
\hline & Részt vevő versenyzők & Esetszponzor \\
\hline ISMERETEK & $\begin{array}{c}\text { A résztvevők új vállalat-, iparág-, } \\
\text { piac-, valamint problémaspecifi- } \\
\text { kus ismeretekkel gazdagodnak. }\end{array}$ & $\begin{array}{l}\text { A résztvevők megismerik az } \\
\text { esetet adó szervezet termékeit, } \\
\text { belső müködését, valamint azt az } \\
\text { iparágat, amelyben működik. }\end{array}$ \\
\hline KOMPETENCIÁK & $\begin{array}{l}\text { A versenyszabályzatban meg- } \\
\text { határozott feltételek között, a } \\
\text { csapatok munka közben (on the } \\
\text { job) fejleszthetik a problémameg- } \\
\text { oldó képességüket. }\end{array}$ & $\begin{array}{l}\text { Az esetszponzor zsűritagként } \\
\text { felmérheti a résztvevők - mint } \\
\text { potenciális munkavállalók - prob- } \\
\text { lémamegoldó képességét. }\end{array}$ \\
\hline ÖTLETEK & $\begin{array}{l}\text { A résztvevők saját ötleteiken, } \\
\text { javaslataikon keresztül alakíthat- } \\
\text { ják egy szervezet működését. }\end{array}$ & $\begin{array}{l}\text { A résztvevők új ötletekkel gaz- } \\
\text { dagodhatnak, valamint a megléró } \\
\text { ötleteiket validálhatják a csapatok } \\
\text { által elkészített megoldásokon } \\
\text { keresztül. }\end{array}$ \\
\hline
\end{tabular}

Forrás: saját koncepció (2018)

\section{A KUTATÁS MÓDSZERTANA"}

A tanulmány módszertana egy 2017 márciusában végzett fókuszcsoportos kutatásra, valamint a 2017 szeptember-novemberében először megrendezett „Biztosítsd Be Magad” esettanulmány-verseny tapasztalataira épül. 


\section{1. Fókuszcsoportos kutatás}

A MABISZ Fiatal generációs stratégia munkacsoportjában felmerült az igény, hogy alaposabb ismereteket szerezzenek az Y generációs fiatalok biztosítókról alkotott véleményéröl. A MABISZ azt szerette volna megtudni, hogy a korcsoport tagjai mit gondolnak a biztosítókról. A fiatalok mint potenciális fogyasztók és mint leendő munkavállalók is érdekesek lehetnek a stratégiaalkotásban.

A kutatómunka során a célcsoport véleményét és ismereteit fókuszcsoportos módszerrel tártuk fel. A módszer fő előnye, hogy a MABISZ munkacsoport tagjai elmélyültebb ismereteket szerezhettek a témában, valós időben hallva az információkat közvetlenül a célcsoporttól. A fókuszcsoport az alábbi módon épült fel:

- 5 fó

- $\quad$ 19-22 éves alapszakos egyetemi hallgatók

- üzleti, gazdaságinformatikus, tervező grafikus és szociológus hallgatók

A rendelkezésre álló egy órában a munkacsoport tagjai két blokkban hallhatták a résztvevők véleményét (lásd 4. táblázat). Az első kérdésblokkban előzetes tájékoztatás nélkül (a résztvevők nem tudták, hogy a MABISZ-hoz jönnek) mértük fel a hallgatók ismereteit a biztosítói szakmáról és termékekről. Mindezt egy reflexió követte, ahol a munkacsoport tagjai kifejthették véleményüket a hallottakról. A fókuszcsoport 2. blokkjában a hallgatók - részben a hallottak alapján - válaszoltak további, a részletekbe menő kérdésekre.

\section{4. táblázat: A fókuszcsoportos felmérés menetrendje}

\begin{tabular}{l|ll}
\multicolumn{2}{l}{ Leírás } & Hossz (perc) \\
\hline \multirow{2}{*}{$\begin{array}{l}\text { Megnyitó } \\
\text { 1. kérdésblokk }\end{array}$} & Az agenda ismertetése & 5 \\
Reflektálás & Fókuszcsoportos beszélgetés & 20 \\
2. kérdésblokk & A MABISZ-os kollégák reflektálása az 1. blokkra & 15 \\
Reflektálás & Fókuszcsoportos beszélgetés & 20 \\
Következö lépések & Rövid reflektálás a 2. kérdésblokkra & 10 \\
& Következỏ lépések átbeszélése (a hallgatók nélkül) & 20
\end{tabular}

Forrás: saját koncepció (2018)
Miután a moderátor bemutatta a fókuszcsoport koncepcióját, egy rövid, a témára történő ráhangolódás következett. A két kérdésblokkban körbejárt kérdéseket az 5. táblázat foglalja össze:

\section{5. táblázat: A fókuszcsoportos felmérés vezérfonala}

1. KÉRDÉSBLOKK: ÁLTALÁNOS KÉRDÉSEK

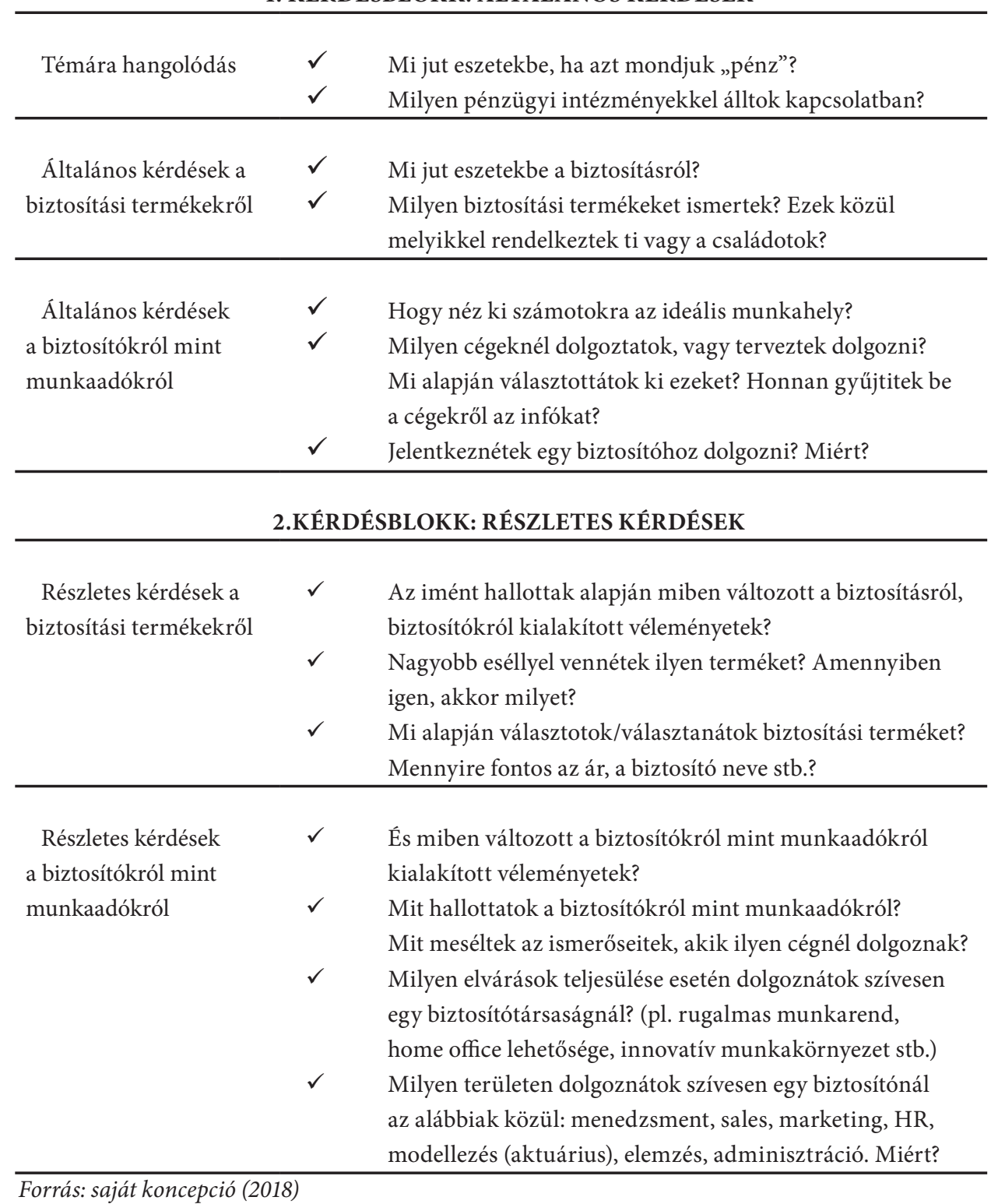




\section{2. „Biztosítsd Be Magad” - esettanulmány-verseny}

A „Biztosítsd Be Magad” esettanulmány-verseny célja a magyar biztosítási iparág népszerüsítése volt az Y generáció körében. Mindez egyszerre jelenti az alapvető biztosítási ismeretek terjesztését, a fiatalok edukációját, valamint a biztositók és a fiatalok közötti távolság csökkentését is. A verseny szervezése során fontos célként jelent meg a fiatalok biztosítási szektorral kapcsolatos véleményének és ötleteinek a becsatornázása a MABISZ és az iparág szereplöinek a müködésébe.

A verseny 2017 szeptembere és novembere között került megrendezésre. A versenyre a szervezők 2 fös csapatok jelentkezését várták, akik egy játékos online forduló után egy Harvard-stílusú esettanulmányt oldottak meg két hét alatt.

A verseny döntőjére a részt vevo csapatok egy kitalált magyarországi biztosító, a „Delta Biztosító” esetével foglalkoztak két héten keresztül. A feladat megoldása során a résztvevők arra keresték a választ, hogyan tudja a „Delta Biztositó” követni a legújabb digitalizációs trendeket, és ezekre építve hogyan tudja megcélozni az Y generáció tagjait. Mindezek alapján átgondolták az egyes online platformok müködését, valamint azt, hogyan tudná a „Delta Biztosító” a megfelelő online jelenlét kialakításával növelni az ismertségét az Y generáció körében. A csapatok az Y generáció megcélzásáról szóló stratégiát alakítottak ki és prezentáltak a biztosítási szektor szakértőiből álló zsüri előtt.

A csapatoktól a szakmai zsűri tehát azt várta, hogy átfogóan vizsgálják meg az esettanulmányban megfogalmazott kérdéseket, javasoljanak innovatív ötleteket a megfogalmazott kihívások kezelésére, ismertessék azok megvalósitásának főbb lépéseit, erőforrásigényét, kockázatait, valamint azonosítsák a várható eredményhatásokat.

A kutatás során három szempont alapján elemeztük a csapatok által beküldött megoldásokat. A kutatás során alkalmazott szempontok nem azonosak a verseny során használt értékelési kritériumokkal. A megoldások elemzése során azt vizsgáltuk, hogy az esettanulmány-módszeren keresztül a) mennyiben sikerült megérteni az iparág működését, hogyan illeszkednek a Delta Biztosító stratégiájához, b) a javasolt megoldások mennyiben megvalósíthatók, valamint azt, hogyc) azötletek mennyire kreatívak. A megoldások értékeléséhez kapcsolódó pontrendszert a 6. táblázat mutatja be.

\section{6. táblázat: A versenyre beküldött megoldások elemzési kerete}

\begin{tabular}{|c|l|l|l|}
\hline Pont & Stratégiai illeszkedés & Megvalósíthatóság & Kreativitás \\
\hline 1 & $\begin{array}{c}\text { A logikai érvelés teljes } \\
\text { hiánya, a javasolt megol- } \\
\text { dás nincs párhuzamban az } \\
\text { iparági trendekkel és a „Delta } \\
\text { Biztosító” stratégiájával. }\end{array}$ & $\begin{array}{c}\text { Az esettanulmányban } \\
\text { leírt információk alapján } \\
\text { nem megvalósítható a } \\
\text { megoldás. }\end{array}$ & $\begin{array}{l}\text { Nincsenek az esettanul- } \\
\text { mányban említetteken } \\
\text { felül kreatív ötletek. }\end{array}$ \\
\hline
\end{tabular}

\begin{tabular}{|c|c|c|c|}
\hline 2 & $\begin{array}{l}\text { Részben tartalmaz a megol- } \\
\text { dás logikus érvelést, de csak } \\
\text { elszórtan, néhány ponton } \\
\text { kapcsolódik a tanulmányban } \\
\text { leírt stratégiához. }\end{array}$ & $\begin{array}{l}\text { Az esettanulmányban } \\
\text { leírt információk alapján } \\
\text { inkább nem valósítható } \\
\text { meg a megoldás, mint } \\
\text { igen. }\end{array}$ & $\begin{array}{l}\text { Egy-egy ötlet megjele- } \\
\text { nik a leadott megoldás- } \\
\text { ban. }\end{array}$ \\
\hline 3 & $\begin{array}{l}\text { A megoldási javaslat kb. } \\
\text { 50\%-ban illeszkedik az eset- } \\
\text { ben leírt stratégiához. }\end{array}$ & $\begin{array}{l}\text { Az esettanulmányban } \\
\text { leírt információk alapján } \\
\text { kb. 50\%-ban megvalósít- } \\
\text { ható a megoldás. }\end{array}$ & $\begin{array}{l}\text { Egy-egy ötlet megjele- } \\
\text { nik a leadott megoldás- } \\
\text { ban. }\end{array}$ \\
\hline 4 & $\begin{array}{l}\text { Jól felépített, a stratégiához } \\
\text { illeszkedő megoldás, mely } \\
\text { azonban elszórtan tartalmaz } \\
\text { inkonzisztens elemeket. }\end{array}$ & $\begin{array}{l}\text { Az esettanulmányban } \\
\text { leírt információk alapján } \\
\text { inkább megvalósítható a } \\
\text { megoldás. }\end{array}$ & $\begin{array}{l}\text { Újszerủ megközelítések } \\
\text { is megjelennek az apróbb } \\
\text { otletek mellett. }\end{array}$ \\
\hline 5 & $\begin{array}{l}\text { Jól felépített érvelés, mely } \\
\text { teljes mértékben illeszke- } \\
\text { dik az esettanulmányban } \\
\text { bemutatott „Delta Biztosíto’” } \\
\text { stratégiájába. }\end{array}$ & $\begin{array}{l}\text { Az esettanulmányban } \\
\text { leírt információk alapján } \\
\text { megvalósítható a megoldás. }\end{array}$ & $\begin{array}{l}\text { Radikálisan új megkö- } \\
\text { zelítések, „out of the box” } \\
\text { ötletek. }\end{array}$ \\
\hline
\end{tabular}

Forrás: saját koncepció (2018)

Az 5. táblázatban bemutatott három szemponton keresztül definiáltam a biztosítási szektor ismertségét.

\section{A KAPOTT EREDMÉNYEK BEMUTATÁSA}

\section{1. Fókuszcsoportos kutatás}

A fókuszcsoportos kutatás a biztosítási termékek, valamint a biztosítók mint munkaadók ismertségét vizsgálta. A kutatásból kiderült, hogy az Y generáció tagjai nem ismerik a biztosítási termékeket, illetve a biztosítókról mint munkaadókról alkotott képük lényegesen eltér a saját igényeiktől. Először tekintsük át a biztosítási termékek ismertségére vonatkozó eredményeket: 
$\checkmark \quad$ Nem értik a termékeket. A biztosítási termékekkel közvetlenül nem találkoznak, így nincsenek rákényszerítve arra, hogy megértsék a termék működését. „Anyukám mondta, hogy kötött nekem háztartási biztositást." - hangzott el az egyik résztvevőtől a beszélgetés során. A fenti idézet jól szemlélteti, hogy nem ismerték a biztosítási termékeket a fókuszcsoport résztvevői.

$\checkmark \quad$ Nagymértékben támaszkodnak a szülökre. A fontosabb döntések előtt többnyire kikérik a szüleik véleményét. „A szüleim mindig mondják utazás elött.” - hangzott el az utasbiztosításokat firtató kérdésre adott válasz. A sajátos élethelyzet miatt a fiatalok még nem hoznak önálló döntést, a biztosításokkal kapcsolatban a szülők véleményére támaszkodnak.

$\checkmark \quad$ Sztereotípiákkal rendelkeznek. Az Y generáció tagjainak többnyire nincs személyes tapasztalatuk, csak hallomásból ismernek dolgokat. Általános pszichológiai mintázatnak tekinthető, hogy a negatív hírekre jobban emlékszünk. A biztosításközvetítőkről szóló beszélgetés során az egyik résztvevő az alábbi kérdést tette fel: „A biztositásközvetítő olyan, mint egy ... ügynök? Csak nem?!". Mint hozzátette, gyerekkorából él benne egy olyan kép, ahogy a szülei komoly dolgokról beszélgetnek az étkezőasztalnál egy számára idegen hölggyel.

$\checkmark \quad$ Élményközpontú életszemlélet. A generáció tagjainak hétköznapjait nagymértékben az élményszerzés (pl. utazás) és más közösségi tevékenységek (pl. szórakozás) teszik ki. „Szabadidőmben a barátaimmal beülök sörözni, vagy elutazom valahová, ha éppen a pénztárcám engedi”. A 18-25 éves korosztály az egyetemista létből fakadóan speciális élethelyzetben van, mely élethelyzet az élmények köré épül. A vizsgált csoportnak sok szabadideje van, ellenben általában nem rendelkezik önálló jövedelemmel.

$\checkmark \quad$ Árérzékenység. Mivel sokan még nem rendelkeznek önálló keresettel, ezért rendkívül árérzékeny a vizsgált csoport. „Azért dolgozok, hogy az egyetemi tanulmányaimat és a diákéveimet finanszírozzam”. Az árérzékenység miatt a fiatalok fogyasztási kosarában a biztosítási termékek hátul szerepelnek.

$\checkmark$ Rövid távon gondolkodnak. Az egyetemista diákok jellemzően 1-3 éves időtávon gondolkodnak, és gondolkodásukat jellemzően a karrier és magánéleti kérdések határozzák meg. „Jelenleg az egyetemi tanulmányaimra és a diákszervezeti feladataimra koncentrálok.”

\section{A kutatásból kiderültt, hogy az Y generáció tagjai nem ismerik \\ a biztosítási termékeket.}

A biztosítókról mint munkaadókról alkotott kép is lényegesen eltér a valóságtól. A beszélgetés során kiderült, hogy a fiatal egyetemista hallgatókból álló csoport nincs tisztában azzal, hogy milyen típusú állás- és karrierlehetőségeket kínál egy biztosító. A fókuszcsoportos beszélgetés során többen is kiemelték, hogy nem ismerik a biztosítókat, nem találkoznak velük az egyetemen. Többen megemlítették, hogy az álláskeresés során az egyetemen hallott információkra támaszkodnak.

\section{2. „Biztositsd be magad” verseny}

A 2017 őszén megszervezett „Biztosítsd be magad” esettanulmány-versenyen 41 csapat vett részt. A csapatok egy online fordulót követően egy kitalált, a „Delta Biztosító” névvel ellátott biztosítótársasághoz kapcsolódó esettanulmányt oldottak meg. A megoldásokat 16 csapat adta le, melyeket a kutatásom céljából elemeztem, és a kapott eredményeket a vizsgálati szempontok alapján strukturáltam:

Stratégiai illeszkedés: Az elkészített megoldások a stratégiai illeszkedés szempontjából 2.87/5.00 pontot kaptak az értékelés során. A három vizsgált tényező közül ez a kategória kapta a legalacsonyabb pontokat. Egyrészt az elkészített megoldások reflektáltak az esettanulmányban felvetett két kérdésre, mely a „Delta Biztosító” digitalizációs stratégiájára, valamint az Y generáció elérésére vonatkozott, másrészt a javasolt megoldások egy része nem illeszkedett szervesen az esetben felvázolt stratégiai célokhoz.

Megvalósíthatóság: A javasolt ötletek megvalósíthatósága is széles skálán mozgott. Voltak csapatok, akik nyereményjátékokkal és más kampányokkal hívnák fel a fiatalok figyelmét a biztosítás fontosságára, míg mások online és offline képzéseket tartanának a fiatalok számára. Voltak csapatok, akik a mesterséges intelligencia, kiterjesztett valóság vagy chatbotok alkalmazását javasolták. A megvalósíthatóság szempont átlag pontszáma 3.13 /5.00.

Kreativitás: Az értékelés során a kreativitás kategória kapta a legmagasabb pontszámot (3.33/5.00). A kapott megoldások közül mindegyik valamilyen új termék vagy szolgáltatás bevezetésére irányult. Volt, aki InsurTech inkubátor programmal állt elő, míg volt olyan csapat, amelyik mobilapplikációt fejlesztett volna. A csapatok nagy része márkanevet adott a javasolt terméknek, szolgáltatásnak, és annak bevezetésére és működésére implementációs tervet dolgozott ki.

A kapott megoldások vizsgálata után megállapíthatjuk, hogy az eseményen részt vevő diákok minőségi időt töltöttek el a biztosítási szektorral kapcsolatos kérdések megoldásával. A kapott megoldások a biztosítási szektor szereplői számára releváns javaslatokat tartalmaztak, melyek illeszkedtek az iparági trendekbe. A javaslatok egy része a technológiai trendek és a digitalizáció hatására helyezte a hangsúlyt, és ezekhez kapcsolódóan lehetséges alkalmazási területeket azonosított például a virtuális valóság vagy chatbotok alkalmazására. Mások az online kurzusokon, tantermi figyelemfelkeltő órákon, versenyeken és más eseményeken keresztüli edukációra tettek javaslatot.

\section{KÖVETKEZTETÉSEK}

Kutatómunkám során arra a kérdésre kerestem a választ, hogy miként növelhető a biztosítási piac ismertsége az Y generáció tagjainak körében az esettanulmány-módszeren keresztül. A módszer egyszerre alkalmas arra, hogy új - iparág-, vállalat-, probléma- és funkcionális terület specifikus - ismereteket adjon át, valamint, hogy fejlessze a diákok problémamegoldó képességét. 
A kutatómunka első fázisában felmértem az iparág ismertségét egy egyetemista résztvevőkből álló fókuszcsoportos kutatáson keresztül, majd a „Biztosítsd Be Magad” esetverseny példáján keresztül megvizsgáltam, hogy a verseny mennyiben járult hozzá a résztvevők biztosítópiaci ismereteinek a bővüléséhez. A kutatás során nem tértem ki külön a versenyhez kapcsolódó kommunikációs ismertségre, a fókusz végig az üzleti és szakmai tartalom átadása volt.

A fókuszcsoportos kutatásból kiderült, hogy a részt vevő egyetemisták nem ismerik az iparágat, a biztosítási termékeket, és a biztosítók nem szerepelnek potenciális munkaadóként a fejükben. Mindez magyarázható a speciális élethelyzettel és azzal, hogy nem érzik még szükségét annak, hogy mélyrehatóbban foglalkozzanak biztosítási termékekkel. Nem rendelkeznek még jelentősebb vagyontárgyakkal (pl. lakás, gépjármü). Az élethelyzeten túl a megfelelő információk sem jutnak el hozzájuk, mivel más kommunikációs csatornákat használnak.

A módszertan második pillérét a „Biztosítsd Be Magad” esettanulmány-verseny jelentette, ahol a 2. fordulóhoz kiadott, „Delta Biztosító”-ról szóló esettanulmányra beérkezett megoldásokat értékeltem a szakmai ismertség szempontjából. A beérkezett javaslatok alapján megállapítható, hogy a diákok felmérték a hazai és nemzetközi biztosítási piac müködését, és ennek alapján fogalmazták meg kreatív ötleteiket. Mivel a csapatok két hétig dolgozhattak a megoldásukon, így volt idejük részleteiben megismerni az iparág müködését.

A kutatás arra a kérdésre kereste a választ, hogy mennyire ismert a biztosítási szektor az Y generáció körében, illetve az ismertséget hogyan lehet javítani a szektor esetében az esetversenyeken keresztül. Az esemény után a versenyzők egyértelműen úgy nyilatkoztak, hogy a feladatokon keresztül megismerték az iparág működését. Mindezek alapján megállapíthatjuk, hogy a módszer alkalmas arra, hogy egy-egy iparág, vállalat ismertségét növelje a fiatal generáció tagjai körében, de vannak korlátai. A módszerrel jelenleg az üzleti hallgatók egy szűk körét lehet elérni, mivel a feladat megoldása során szükség van üzleti képzettségre. A kutatás másik fontos következtetése, hogy azok a diákok, akik részt vettek a „Biztosítsd Be Magad” versenyen, részleteiben ismerték meg az iparág és a biztosítók működését.

\section{HIVATKOZÁSOK}

'A Case Solvers egy 2012 öszén alapított, az esettanulmány megoldásának oktatására szakosodott vállalkozás. Az esettanulmány-megoldás mellett tehetséges fiatalokat készit fel hazai és nemzetközi esettanulmány-versenyekre. A szerzô a Case Solvers egyik alapitója.

setszponzor lehot forproper típusa a tapasztalatok alapján nagymértékben befolyásolja az esettanulmány témáját.

\section{IRODALOMJEGYZÉK}

Boyatzis R. E. - Stubs E. C. - Taylor S. N. (2002): Learning Cognitive and Emotional Intelligence Competencies Through Graduate Management Education. In: Academy of Management Learning \& Education. Vol. 1. No. 2. pp. 150-162.

https://doi.org/10.5465/amle.2002.8509345

Erskine, J. A., - Leenders, M.R. - Mauffette-Leenders, L. A. (1998): Teaching with cases. London. Ivey Publishing. Ivey School of Business Administration.

at. Pécsi Tudományegyetem, Közgazdaságtudományi Ka

A. (2002): Learning by the Case Method. Harvard Business School. 2002. April

Jerrad, M. A. (2005): Assessing student learning and skills using the case study method. In. Journal of Management Education. Vol (2), $\mathrm{pp} .181-194$.

Experientally through Case Studies? A Conceptual Analysis, Teaching in Higher Education. pp. 217-228. Kulcár Zs.org/10.1080/13562510120045203

Kunselman I. C. J Jhnson, K. A. (2004): Using the Case Method to Facilitate Learning In. College Teaching. 55.3. pp 87-92. https://doi.org/10.3200/ctch.52.3.87-92

Levin, B. B. (1995): Using the case method in teacher education: The role of discussion amd experience in teachers' thinking about cases. In: Teaching and Teacher Education, Vol 11., pp. 63-79.

https://doi.org/10.1016/0742-051x(94)00013-y

Maier-Lytle, J. - McGuire, B. - Ehlen C. R. (2010): Case Study Competitions Give Accounting Students a Competitive Edge. In: Management Accounting Quarterly. Vol. 11. No. 4.

McCrindle. M - Wolfinger, E. (2010): Az XYZ abeceje. A nemzedekek meghatarozasa. In: Korunk. vol. 3. No. 11. pp. 13-18. Meretei, B. (2017): Generációs különbségek a munkahelyen. Szakirodalmi áttekintés. In: Vezetéstudomány. Vol. 48. No. 10. pp. 10-18. https://doi.org/10.1426/veztud.2017.10.02

Merseth, K. (1991): The early history of case-based instruction: Insights for teacher education today. In: Journal of Teacher Education. Vol. 42(4), pp. 243-249.

https://doi.org/10.1177/002248719104200402

hetps/doi 0 / $101111 / 1748-121 \times 1991$ tb00554 x 